\title{
Occurrence of Public Health and Environmental Hazards and Potential Remediation of Arsenic-Containing Soils, Sediments, Surface Water and Groundwater at the Lava Cap Mine NPL Superfund Site in \\ Nevada County, California*
}

G. Fred Lee, PhD, PE, DEE and Anne Jones-Lee, PhD

G. Fred Lee \& Associates

27298 E. El Macero Drive

El Macero, CA 95618

email: gfredlee@aol.com

www.gfredlee.com

\begin{abstract}
In 1999 the US EPA added the Lava Cap Mine area to the National Priority List (NPL) Superfund sites. This site is a former gold and silver mine located in Nevada County, California, near Nevada City. The area is a Sierra-Nevada foothill wooded area, with low-density residential development. A risk assessment shows that there are significant potential human health and ecological risks associated primarily with arsenic in the mine site area tailings, the creeks that have received tailings discharges, and in the Lost Lake area. The US EPA has proposed several potential remediation approaches, which include containment with capping of existing contaminated areas, or excavation of tailings and tailings-contaminated areas and disposal in a new landfill in the area, or transported offsite for disposal. Further, consideration is given to treatment of the contaminated soils and sediments to immobilize arsenic.

An issue that will need to be resolved is the cleanup goal for groundwaters contaminated by waste-derived arsenic. While the contaminated soil and water cleanup objectives have not been established, the US EPA has indicated that the recently adopted $10 \mu \mathrm{g} / \mathrm{L}$ drinking water maximum contaminant level (MCL) is a potential cleanup objective for water contaminated by arsenic. However, there are questions as to whether a risk-based drinking water cleanup objective should be used which does not consider economic and political factors that were incorporated into the $10 \mu \mathrm{g} / \mathrm{L}$ MCL adopted by the US EPA. Another important issue is the ability of the standard RCRA landfill to prevent further groundwater pollution by landfilled arsenic-containing soils and tailings for as long as the landfilled tailings represent a threat. As currently developed, RCRA landfills only postpone groundwater pollution.
\end{abstract}

Key words: arsenic, Lava Cap Mine, Superfund, gold mine tailings, remediation, groundwater, landfills, Nevada County, CA.

\section{INTRODUCTION}

The Lava Cap gold and silver mine was a shaft mine that started operating in 1861, and operated periodically until 1943. It was one of the largest gold mines in California. This mine is located about five miles from Nevada City, California, in the foothills of the Sierra-Nevada mountains. The elevation of the mine site is about 818 meters. Figure 1 shows a general map of the Lava Cap Mine Superfund site area.

* to be published in the proceedings of the Fifth International Conference on Arsenic Exposure and Health Effects, San Diego, CA, July 2002, Society for Environmental Geochemistry and Health, Elsevier Science, Inc.(2003). 
Figure 1

Map of Lava Cap Mine Superfund Site Area

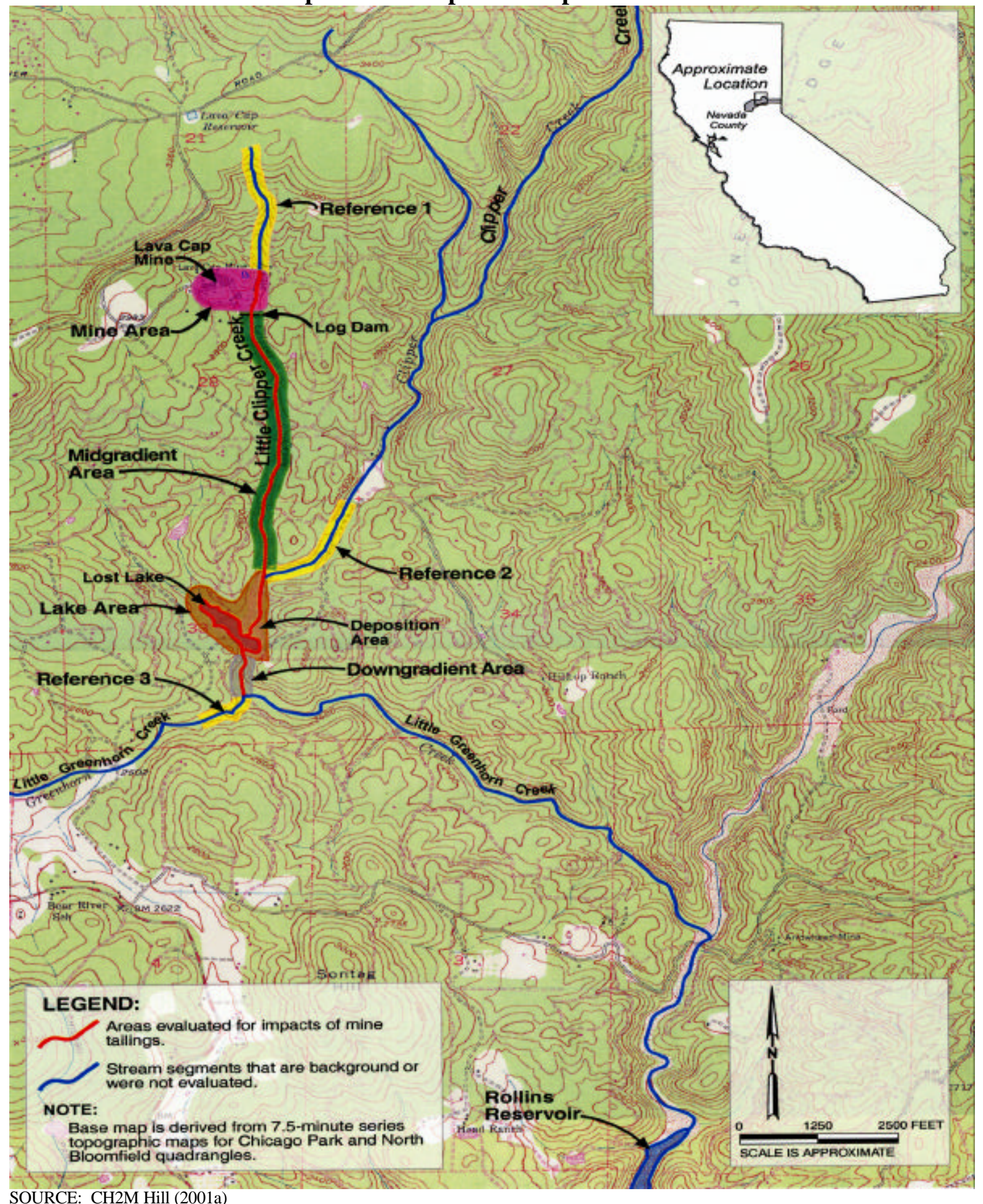

SOURCE: CH2M Hill (2001a) 
The Lava Cap Mine site occupies about 12 hectares. It is in a forested, low-density residential area, with a small stream and a log tailings dam located at the mine site, and another tailings storage area (Lost Lake) located several kilometers downstream. Lost Lake is a private lake surrounded by homes located about 2 kilometers downstream from the Lava Cap Mine site. According to the US EPA(2002), in 1994 an estimated 1,776 people lived within one mile of the contaminated area and 24,091 lived within four miles of the area. The ore processed for gold and silver recovery contained high levels of pyrite, arsenopyrite and galena. The ore was processed by crushing and grinding, followed by either flotation or cyanide treatment. Some of the ore was processed by amalgamation with mercury.

Following the partial collapse of a 9-meter-high log based tailings dam in January 1997, which released about 7,650 cubic meters of tailings to Little Clipper Creek (a small stream draining the area), Clipper Creek, Little Greenhorn Creek and Lost Lake (a tailings reservoir), in October 1997, the US EPA initiated a "removal action" to prevent further tailings release from the log-based dam. The tailings dam stores about 38,000 cubic meters of tailings. Lost Lake was developed as a tailings storage area, with a 15-meter-high earthen dam. It is estimated to contain about 115,000 cubic meters of tailings. The Deposition Area just upstream of Lost Lake is estimated to contain 268,000 cubic meters of tailings (see Figures 1 and 2).

CH2M Hill, Inc., of Sacramento, CA, with several subcontractors, is the US EPA contractor for the Remedial Investigation Feasibility Study (RI/FS). David Seter is the US EPA Region 9 project manager, with Don Hodge as the community involvement coordinator. The California Department of Toxic Substances Control, under the leadership of Steve Ross, is involved in reviewing the US EPA site investigation and remediation studies. Further, the California Department of Health Services has conducted a review (ATSDR, 2001) of the public health hazards of the site. The California Department of Fish and Game (Salocks, 1997) has conducted a review of the potential impacts of the tailings dam failure and the associated release of tailings on wildlife. The South Yuba River Citizens League (SYRCL) is the public representative for a US EPA Technical Assistance Grant. Janet Cohen is the Executive Director of SYRCL. The US EPA Technical Assistance Grant advisor is Dr. G. Fred Lee, of G. Fred Lee \& Associates, El Macero, California. The RI/FS is being conducted by the US EPA Region 9 since, at this time, there is no identified responsible party that can fund the investigation and cleanup. Funding is, therefore, being provided by the US EPA.

The US EPA Region 9 is the lead agency conducting the CERCLA remedial investigation and feasibility study for the purpose of:

$\$$ assessing the contamination associated with the Lava Cap Mine Superfund site and

$\$$ development of remedial alternatives for arsenic-contaminated soil, sediment, surface water and groundwater.

The US EPA has provided a summary of the Lava Cap Mine Superfund site issues on the Internet (US EPA, 2002). The Agency has released a series of contractor reports (CH2M Hill, 2001a,b,c; 2002) which serve as the background for the information provided in this paper on the characteristics of the site. The materials presented in this paper are largely derived from the investigations of the US EPA and its contractor, $\mathrm{CH} 2 \mathrm{M}$ Hill. 


\section{PUBLIC HEALTH AND ENVIRONMENTAL PROBLEMS}

After extensive monitoring of the mine area and downstream where tailings have been carried through deliberate discharges and the failure of the log-based tailings dam, it has been found that there is extensive surface soil, water and sediment contamination by arsenic derived from the tailings. Table 1 presents a summary of the data obtained in the studies that have been conducted thus far. Some of the soils have been found to contain as much as $34,000 \mathrm{mg} / \mathrm{kg}$ arsenic. As shown in Table 1, the reference areas selected by the US EPA typically contained on the average of 10 to $20 \mathrm{mg} / \mathrm{kg}$ arsenic, while the surface soils in the mine area contained on the average of about 2,000 mg/kg. The surface soil area along Little Clipper Creek below the log dam had around $600 \mathrm{mg} / \mathrm{kg}$ arsenic. The tailings Deposition Area near Lost Lake contained about $500 \mathrm{mg} / \mathrm{kg}$, and Lost Lake sediments had about $700 \mathrm{mg} / \mathrm{kg}$ arsenic. There is significant contamination of surface areas by arsenic that are readily accessible to the public by the tailings releases that have taken place in the past.

A standard CERCLA RI/FS risk assessment has shown that the mine area, which includes the tailings dam, the soils and sediments along Little Clipper Creek, Clipper Creek, Little Greenhorn Creek and near Lost Lake, and downstream of Lost Lake to some yet-undefined extent, are contaminated with sufficient arsenic to be a threat to human health through body contact (US EPA, 2000, 2001a). The risk assessment is based on the Guidelines for Conducting Remedial Investigation and Feasibility Studies under CERCLA (US EPA, 1989). The goal of the remedial investigation is to reduce the excess lifetime cancer risk associated with arsenic to the range of $10^{-4}$ to $10^{-6}$ additional cancers. The remedial investigation non-cancer risk goal is to achieve background levels. Arsenic is the primary human health and ecological risk driver for the Lava Cap Mine site (US EPA, 2001a; CH2M Hill, 2001a). In addition, for ecological risk, antimony, cadmium, copper, cyanide, lead, mercury, silver and zinc have been found thus far to contribute to risk to aquatic and terrestrial wildlife (CH2M Hill, 2001b). Further, there is a potential for airborne tailings (dust) to be a problem for the residents and wildlife of the area, which has not been adequately evaluated at this time.

According to CH2M Hill (2001a), the total estimated lifetime cancer risk for residents and recreational users around Lost Lake is about $5 \times 10^{-5}$. Along Clipper Creek, it is about $1 \times$ $10^{-3}$. In the Deposition Area (see Figure 2) near Lost Lake, it is also about $1 \times 10^{-3}$. The noncancer hazard risk for residents in the Lost Lake vicinity had an exposure quotient of 6.3. For residents along Clipper Creek, it was 6.3 to 10, and for recreational users of the Deposition Area above Lost Lake, it was 28.

There are seeps from abandoned mine shafts which are discharging high arsenic concentrations and other contaminants. Further, the interstitial waters within the tailings and below the tailings pile located near the mine contain elevated arsenic, with some groundwaters near the mine site having arsenic in excess of 100 to $500 \mu \mathrm{g} / \mathrm{L}$. The groundwater in the mine area has a complex hydrogeology, consisting of a fractured rock aquifer system. With this aquifer system it will be difficult to trace the movement of mine-tailings-derived arsenic that has polluted the groundwaters in that site to down-groundwater-gradient areas residential wells. 
Table 1

Summary of Arsenic Results in Selected Media - Lava Cap Mine RI Lava Cap Mine, Nevada County, California

\begin{tabular}{|c|c|c|c|c|c|c|}
\hline Description & Media & $\begin{array}{c}\text { Sample } \\
\text { Locations }\end{array}$ & Average & Minimum & Maximum & Units \\
\hline \multirow{4}{*}{$\begin{array}{l}\text { Reference Area } 1 \\
\text { - Above Mine }\end{array}$} & surface soil & 14 & 21 & 5.2 & 95.3 & $\mathrm{mg} / \mathrm{kg}$ \\
\hline & sediment & 7 & 25.8 & 17.9 & 44.3 & $\mathrm{mg} / \mathrm{kg}$ \\
\hline & surface water & 6 & 0.3 & ND & 0.5 & $\mu \mathrm{g} / \mathrm{L}$ \\
\hline & groundwater & 4 & 23.6 & 7 & 36.7 & $\mu \mathrm{g} / \mathrm{L}$ \\
\hline \multirow{3}{*}{$\begin{array}{l}\text { Reference Area } 2 \\
\text { - Clipper Creek }\end{array}$} & surface soil & 3 & 13 & 7.6 & 20.0 & $\mathrm{mg} / \mathrm{kg}$ \\
\hline & sediment & 6 & 13 & 10.9 & 16.0 & $\mathrm{mg} / \mathrm{kg}$ \\
\hline & surface water & 10 & 0.3 & ND & 1.1 & $\mu \mathrm{g} / \mathrm{L}$ \\
\hline \multirow{2}{*}{$\begin{array}{c}\text { Reference Area } 3 \\
\text { - Little } \\
\text { Greenhorn Creek }\end{array}$} & sediment & 1 & 10.1 & 10.1 & 10.1 & $\mathrm{mg} / \mathrm{kg}$ \\
\hline & surface water & 1 & ND & ND & ND & $\mu \mathrm{g} / \mathrm{L}$ \\
\hline \multirow[t]{8}{*}{ Source Areas } & surface soil - mine buildings & 9 & 10,000 & 848 & 31,200 & $\mathrm{mg} / \mathrm{kg}$ \\
\hline & surface soil - waste rock/tailings pile & 6 & 1,340 & 63.6 & 2,070 & $\mathrm{mg} / \mathrm{kg}$ \\
\hline & subsurface soil & 22 & 603 & 15.5 & 5,360 & $\mathrm{mg} / \mathrm{kg}$ \\
\hline & sediment & 1 & 9,201 & 459 & 34,000 & $\mathrm{mg} / \mathrm{kg}$ \\
\hline & surface water - mine buildings & 3 & 4,022 & 68.8 & 14,300 & $\mu \mathrm{g} / \mathrm{L}$ \\
\hline & surface water - adit/seep/log dam & 3 & 233 & 23.6 & 668 & $\mu \mathrm{g} / \mathrm{L}$ \\
\hline & groundwater & 6 & 256 & 12.5 & 567 & $\mu \mathrm{g} / \mathrm{L}$ \\
\hline & ambient air & 2 & N/A & ND & $0.021 \mathrm{~J}$ & $\mu \mathrm{g} / \mathrm{L}^{3}$ \\
\hline \multirow[t]{5}{*}{ Mine Area } & surface soil - around mine buildings & 13 & 2,170 & 79.4 & 5,570 & $\mathrm{mg} / \mathrm{kg}$ \\
\hline & $\begin{array}{l}\text { surface soil - away from waste } \\
\text { rock/tailings pile }\end{array}$ & 25 & 370 & 4.7 & 1,750 & $\mathrm{mg} / \mathrm{kg}$ \\
\hline & surface water & 2 & 10.2 & 1.7 & 31.9 & $\mu \mathrm{g} / \mathrm{L}$ \\
\hline & groundwater - residential wells & 4 & 154 & 11.2 & 528 & $\mu \mathrm{g} / \mathrm{L}$ \\
\hline & ambient air & 1 & N/A & ND & 0.067 & $\mu \mathrm{g} / \mathrm{L}^{3}$ \\
\hline Little Clipper & surface soil & 7 & 599 & 53.9 & 908 & $\mathrm{mg} / \mathrm{kg}$ \\
\hline Creek Below the & sediment & 5 & 669 & 328 & 1,150 & $\mathrm{mg} / \mathrm{kg}$ \\
\hline \multirow[t]{2}{*}{ Log Dam } & groundwater - residential wells & 11 & 9.7 & ND & 46.3 & $\mu \mathrm{g} / \mathrm{L}$ \\
\hline & surface water & 5 & 132 & 19 & 285 & $\mu \mathrm{g} / \mathrm{L}$ \\
\hline \multirow[t]{6}{*}{ Deposition Area } & surface soil & 34 & 459 & 10.2 & 913 & $\mathrm{mg} / \mathrm{kg}$ \\
\hline & sediment & 8 & 615 & 398 & 892 & $\mathrm{mg} / \mathrm{kg}$ \\
\hline & ambient air & 2 & N/A & ND & $\mathrm{ND}$ & $\mu \mathrm{g} / \mathrm{L}^{3}$ \\
\hline & subsurface soil & 18 & 1,430 & 719 & 2,480 & $\mathrm{mg} / \mathrm{kg}$ \\
\hline & groundwater & 4 & 1,180 & 235 & 2,410 & $\mu \mathrm{g} / \mathrm{L}$ \\
\hline & surface water & 4 & 245 & 24.2 & 1,160 & $\mu \mathrm{g} / \mathrm{L}$ \\
\hline \multirow[t]{5}{*}{ Lost Lake } & sediment & 6 & 697 & 304 & 1,140 & $\mathrm{mg} / \mathrm{kg}$ \\
\hline & surface soil & 68 & 288 & ND & 848 & $\mathrm{mg} / \mathrm{kg}$ \\
\hline & ambient air & 1 & N/A & ND & ND & $\mu \mathrm{g} / \mathrm{L}^{3}$ \\
\hline & groundwater - residential wells & 7 & 0.2 & ND & 0.64 & $\mu \mathrm{g} / \mathrm{L}$ \\
\hline & surface water & 3 & 28.4 & 5.8 & 70.6 & $\mu \mathrm{g} / \mathrm{L}$ \\
\hline \multirow{3}{*}{$\begin{array}{l}\text { Downgradient of } \\
\text { Lost Lake }\end{array}$} & surface soil & 2 & 403 & 261 & 673 & $\mathrm{mg} / \mathrm{kg}$ \\
\hline & sediment & 5 & 753 & 38.5 & 2,110 & $\mathrm{mg} / \mathrm{kg}$ \\
\hline & surface water & 4 & 33 & 0.3 & 72.3 & $\mu \mathrm{g} / \mathrm{L}$ \\
\hline
\end{tabular}

$\mathrm{ND}=$ non-detect

$\mathrm{J}=$ estimated concentration

N/A = not applicable because arsenic was either not detected or was only detected once.

SOURCE: CH2M Hill (2002). 
The residents in the area use groundwater as a domestic water supply source. At a US EPA public information meeting held in November 2001, the public participants indicated that their greatest concern was the pollution of their domestic wells by arsenic derived from the mine and/or tailings. This situation is complicated by the fact that some of the groundwaters in the area have been found to contain naturally elevated arsenic. At this time, studies have not been done in sufficient detail to determine the origin of the arsenic present in a number of the domestic water supply wells. Further RI studies are underway to better define the extent of groundwater pollution at the site.

\section{REMEDIATION OPTIONS/OBJECTIVES}

At this time, the cleanup objectives for the Lava Cap Mine Superfund site have not been established (CH2M Hill, 2001c). ARARs (Applicable, Relevant and Appropriate Requirements) are being developed for the site. These will be based on the regulatory requirements of the US EPA, the Central Valley Regional Water Quality Control Board, the California Department of Health Services and the California Department of Toxic Substances Control. Important issues that need to be defined are the appropriate degree of public health and environmental protection that should be achieved at the Lava Cap Mine site, and whether funds will be available to pay for this level of protection. With the Bush administration reducing Superfund support, there is a potential that funds for further investigation and, especially, remediation at the Lava Cap Mine site may be significantly reduced, and possibly eliminated.

\section{Soil Remediation}

Davis, et al. (2001) have recently published a summary of residential and industrial arsenic soil cleanup goals by target risk levels for Superfund sites. This information is presented in Table 2. Based on information in their paper, typically residential areas are cleaned up to about $25 \mathrm{mg} / \mathrm{kg}$ total arsenic, except in California, where the human health cleanup objectives have been about $3 \mathrm{mg} / \mathrm{kg}$. The US EPA has yet to propose the cleanup goals for contaminated soils and sediments for the Lava Cap Mine Superfund site.

Table 2

Summary of Residential and Industrial Cleanup Goals by Target Risk Level

\begin{tabular}{|c|c|c|c|c|c|c|}
\hline \multirow{2}{*}{$\begin{array}{c}\text { target } \\
\text { risk level }\end{array}$} & \multicolumn{2}{|c|}{ residential cleanup goals $(\mathbf{m g} / \mathbf{k g})$} & \multicolumn{2}{c|}{ industrial cleanup goals $(\mathbf{m g} / \mathbf{k g})$} \\
\cline { 2 - 7 } & range & mean $^{\mathbf{a}}$ & $\mathbf{n}$ & range & mean $^{\mathbf{a}}$ & $\mathbf{n}$ \\
\hline $1 \times 10^{-6}$ & $0.37-305$ & 17 & 18 & $8-219$ & 44 & 9 \\
\hline $1 \times 10^{-5}$ & $30-250$ & 68 & 5 & $21-500$ & 65 & 11 \\
\hline $1 \times 10^{-4}$ & $100-230$ & 152 & 2 & $200-336$ & 272 & 3 \\
\hline
\end{tabular}

The geometric mean was used as it best represented the central tendency of the data sets. SOURCE: Davis, et al. (2001)

\section{Groundwater Remediation}

There are several important issues relating to the establishment of the appropriate drinking water cleanup objective for those groundwater supplies that are polluted by arsenic 
wastes (mine tailings). The US EPA, after considerable technical and political debate, finally adopted a revised arsenic drinking water maximum contaminant level (MCL) of $10 \mu \mathrm{g} / \mathrm{L}$. This MCL is to be implemented by 2006. This MCL is not necessarily based on risk. According to the NRC (2001), to achieve a one in a million lifetime additional cancer risk, the drinking water MCL should be set at about $0.1 \mu \mathrm{g} / \mathrm{L}$. A risk-based drinking water MCL is not used, since many domestic water supplies contain arsenic in excess of $0.1 \mu \mathrm{g} / \mathrm{L}$ (Focazio, et al., 1999; USGS, 2002).

One of the factors that played a major role in determining the $10 \mu \mathrm{g} / \mathrm{L}$ MCL was the cost of treatment of domestic water supplies to achieve a lower arsenic concentration (Frost, et al., 2002). Even at $10 \mu \mathrm{g} / \mathrm{L}$, there are about 4,000 domestic water supplies in the US that will need to reduce arsenic in their treated water, at an average household cost of about $\$ 32$ per year, which translates to about 3 cents per person per day for large municipal systems. For small systems, the cost can be as high as 30 cents per person per day. One of the important issues that needs to be resolved at the Lava Cap Mine Superfund site is whether the $10 \mu \mathrm{g} / \mathrm{L} \mathrm{MCL}$ is an appropriate groundwater cleanup objective, where it is clear that the arsenic derived from the mine/tailings is the primary source of the arsenic in the groundwater used or could be used for domestic purposes.

The Central Valley Regional Water Quality Control Board (CVRWQCB) and the US EPA regulate some constituents when derived from wastes, based on a risk-based approach, which requires greater cleanup than when based on a politically/economically-based MCL. Precedent for the risk-based approach stems from the CVRWQCB's requirements for cleanup of waste-derived chloroform at the UCD/DOE LEHR National Superfund site, located on the University of California, Davis (UCD), campus. While UCD attempted to establish the US EPA trihalomethane (chloroform) MCL of $100 \mu \mathrm{g} / \mathrm{L}$ as the chloroform concentration goal for groundwater cleanup, the CVRWQCB determined that that goal was inappropriate, since it was based on a variety of non-risk-related factors, and established a risk-based goal of about $1 \mu \mathrm{g} / \mathrm{L}$. For a discussion of these issues, see the Davis South Campus Superfund Oversight Committee's (DSCSOC) website, http://members.aol.com/dscsoc.

\section{Contaminated Soil/Sediment Remediation Options}

At a US EPA public meeting held in November 2001, US EPA representatives discussed potential remediation options. Figure 2 defines the areas of concern as the Lava Cap Mine, Little Clipper Creek, Clipper Creek, Little Greenhorn Creek, Lost Lake and Deposition Area and downstream of Lost Lake. Table 3 presents a summary developed by the US EPA (US EPA, 2001b; CH2M Hill, 2002) on the potential impacts of the various remedial alternatives. The remedial alternatives being considered by the US EPA include:

\$ "no action," required by CERCLA,

$\$$ institutional controls, where access to the contaminated areas is restricted,

\$ containment, with capping of existing areas, such as tailings stored near the mine site, excavation of tailings and tailings-contaminated soils along the streams, in the streambeds and in the Lost Lake area, with disposal either in a new landfill that would be constructed to contain the excavated tailings or after being trucked out of the area for offsite disposal. 
Figure 2

\section{Lava Cap Mine Superfund Site Remediation Areas}

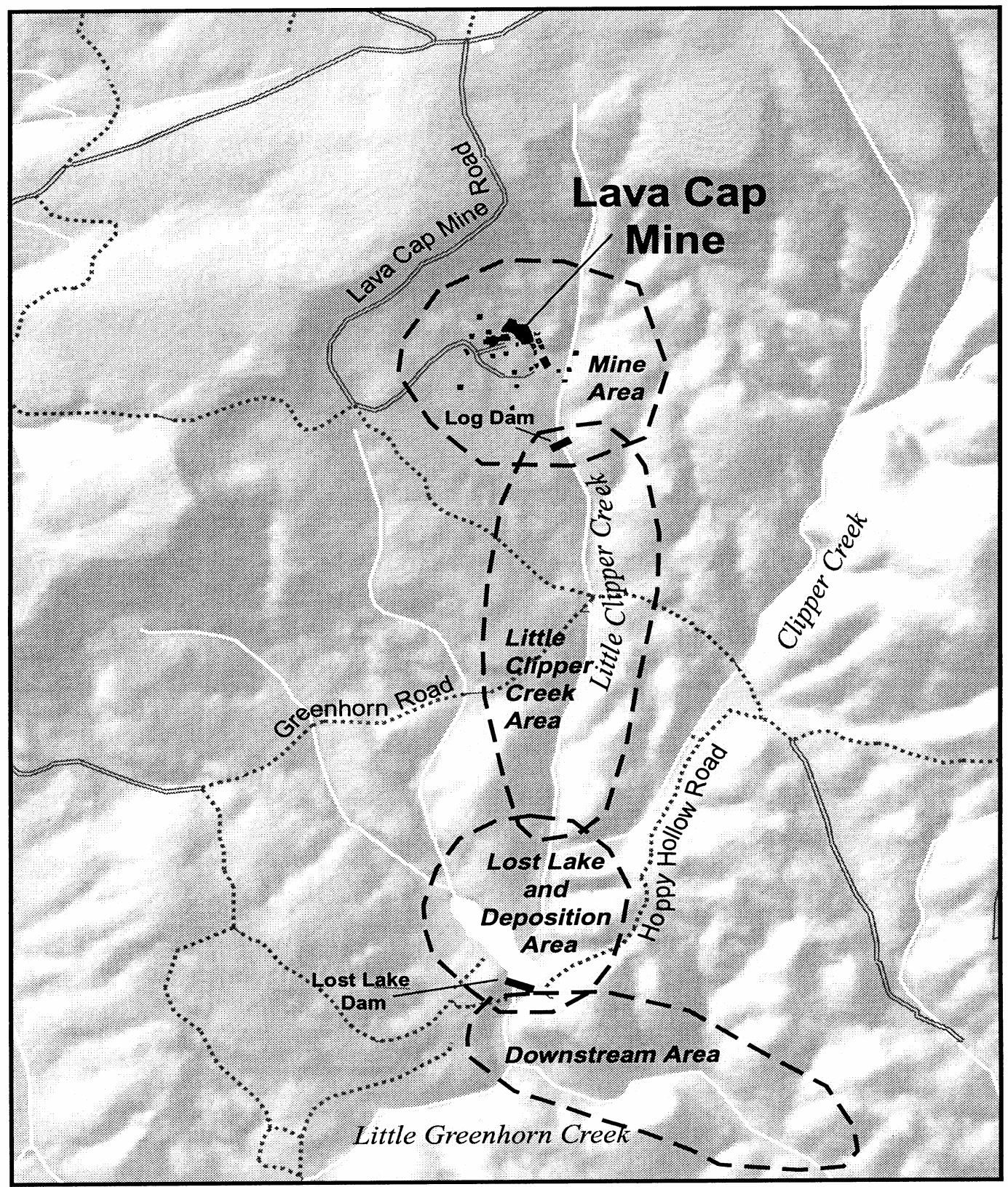

\section{Lava Cap Mine areas}

SOURCE: US EPA (2001b)

"No action" is not an acceptable approach for the tailings contaminated areas because of the widespread human health and ecological risk associated with the dispersion of tailings containing high levels of arsenic and some other constituents. The institutional controls 
approach will be difficult to implement reliably because of the widespread contamination that has occurred and the fact that the public has ready access to arsenic tailings-polluted areas.

Table 3

Possible Impacts to the Community of Different Cleanup Options

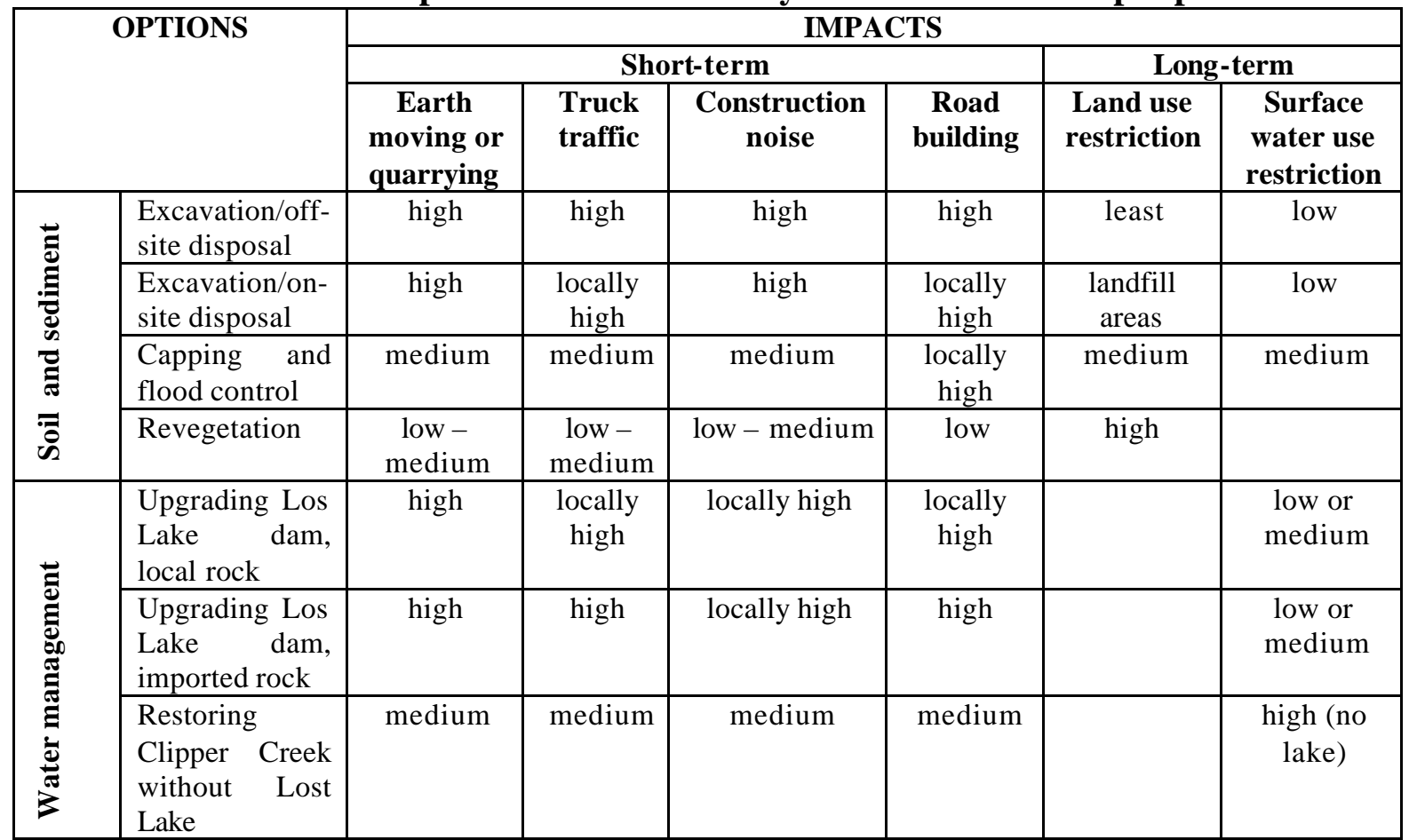

SOURCE: US EPA (2001b)

\section{Preliminary Cost Estimates}

Table 3 lists the general aspects of the potential impacts of these various alternatives. At this time, the US EPA has not provided detailed information on any of the alternatives, and while some preliminary costs have been developed for some of them, these costs are not comprehensive and do not consider some of the important long-term management issues that will have to be addressed as part of remediation of the site using certain of the approaches, such as landfilling. The preliminary cost estimates (Table 4) indicate that excavation with disposal in a new area landfill will cost on the order of $\$ 34$ million, while excavation, trucking and offsite disposal is estimated to cost $\$ 100$ million. Consideration is also given to treatment of the arsenic-containing soils and sediments to immobilize the arsenic. However, none of the potential treatment options appears to be economically feasible.

\section{Remediation Issues}

There are a number of important long-term public health and environmental protection issues that need to be considered in developing an appropriate remediation approach, especially those associated with attempting to use capping of existing tailings/arsenic-polluted areas and/or the construction of a RCRA (Resource Conservation and Recovery Act) landfill cover or landfill in the area to store the contaminated soils and tailings. Typically today in municipal solid waste, industrial non-hazardous waste and hazardous waste management by landfills, the US EPA 
regulations do not provide high degrees of protection associated with the inevitable failure of the plastic sheeting and compacted clay landfill liners and associated covers that are used in Subtitle D (municipal and non-hazardous industrial waste) and Subtitle C (hazardous waste) landfills.

Table 4

Preliminary Cost Estimates by CH2MHill (2002)

\begin{tabular}{|l|c|}
\hline \multicolumn{1}{|c|}{ Area } & $\begin{array}{c}\text { Initial Cost + 50 yrs } \\
\text { Limited Monitoring \& } \\
\text { Maintenance } \\
\text { (million US \$) }\end{array}$ \\
\hline Mine Buildings/Tailings \& Waste Rock Pile & 12 \\
\hline Excavation \& On-Site Disposal & 13 \\
\hline Excavation \& Off-Site Disposal & 15 \\
\hline \hline Little Clipper Creek, Clipper Creek & \\
\hline Capping \& Channelization & 1.9 \\
\hline Excavation \& On-Site Disposal & 0.65 \\
\hline Excavation \& Off-Site Disposal & 0.8 \\
\hline \hline Lost Lake \& Deposition Area & \\
\hline Drain Lake \& Cap Sediment & 8.5 \\
\hline Excavation \& On-Site Disposal & 19 \\
\hline Excavation \& Off-Site Disposal with Removal & 83 \\
\hline of Dam & \\
\hline \hline Downstream of Lost Lake, Clipper Creek \& \\
Little Greenhouse Creek
\end{tabular}
SOURCE: US EPA (2001b)

The Agency's approach focuses on limited-term containment of the waste material for a 30-year post-closure period. It is well-known (see Lee and Jones-Lee, 1998a,b) that the liner systems that are being allowed in Subtitle C and D landfills will eventually fail to prevent leachate from migrating through the liners into the underlying groundwaters and, where 
groundwater surfaces through springs, to the surface waters of the area. Further, as discussed by Lee and Jones-Lee (1998a,b), the groundwater monitoring systems that are being allowed by the US EPA and the state regulatory agencies to be developed at many landfills are significantly deficient in detecting groundwater pollution when it first reaches the underlying groundwaters, before widespread offsite groundwater pollution occurs.

The state of California has significantly more explicit protection of public health and the environment in landfilling than the US EPA and many other states. California requires that the Subtitle C or D landfill be able to prevent impairment of the beneficial uses of groundwaters underlying the landfill for as long as the wastes in the landfill will be a threat. The issue that must be resolved is whether this requirement will be achieved in the remediation of the Lava Cap Mine Superfund site for all wastes (tailings) left in the area.

The basic problem with RCRA landfills is that the US EPA has failed to acknowledge and meaningfully address the protection of groundwaters from pollution by landfill leachate (or, in the case of the Lava Cap Mine site, tailings and arsenic-containing water) for as long as the wastes in the landfill will be a threat. The wastes in a RCRA Subtitle C or D landfill, which would contain tailings from the Lava Cap Mine site, will be a threat to pollute groundwaters, effectively, forever. The liner systems that are allowed, including a double composite liner system, eventually will fail to prevent significant leachate migration through the liner system. This will lead to offsite pollution, due to the fact that the groundwater monitoring systems that are typically used, under ideal conditions, have a low probability of detecting groundwater pollution (see Lee and Jones-Lee, 1998a,b). This situation is even more complex in a geological setting like that of the Lava Cap Mine area, where there is a fractured rock aquifer system, which is virtually impossible to reliably monitor for groundwater pollution.

While landfills can be developed for containment of solid wastes that will protect public health and the environment effectively forever, the initial cost of developing such landfills is about twice to three times that of conventional landfills. Further, and most importantly, there is an ad infinitum monitoring, operation and maintenance cost that must be borne by the responsible parties for managing the wastes in the landfill. The US EPA, as part of RCRA and in accord with the federal Congress' requirements, only requires minimal 30-year post-closure funding for limited monitoring and maintenance of the landfill containment system. There is no assured funding after the landfill has been closed for 30 years. This approach is obviously deficient in providing long-term public health protection from the waste contained in the landfill. Lee and Jones-Lee (1998a) have recommended that, at the time of establishing a landfill for waste management, a dedicated trust fund of sufficient magnitude to address all plausible worstcase failure scenarios for the landfill containment system and monitoring system be developed, which would be expected to generate sufficient funds to operate, monitor and maintain the landfill system forever.

Lee and Jones-Lee (1998a) have discussed approaches for developing landfills that could be used at the Lava Cap Mine site to contain, effectively forever, the tailings and arseniccontaminated soils. This will involve a double composite lined system, with a leak detection 
system between the two liners. When leachate derived from the wastes that contains arsenic that is a threat to cause groundwater pollution passes through the upper composite liner, then either the wastes must be removed from the landfill, or a leak-detectable cover should be placed over the landfill which would be operated and maintained ad infinitum to prevent moisture from entering the landfill for as long as the wastes represent a threat.

\section{CONCLUSIONS}

The Lava Cap Mine Superfund site area is highly contaminated with tailings that contain, in some cases, greatly elevated arsenic. This arsenic is a threat to human health through contact recreation and potentially contaminated groundwater. Further work needs to be done to define the existing and potential groundwater pollution that has occurred due to the Lava Cap Mine and its tailings. In addition to the human health threat, the tailings are also a threat to aquatic and terrestrial life by arsenic and a variety of other heavy metals derived from the former mining activities.

While the US EPA has indicated that the $10 \mu \mathrm{g} / \mathrm{L}$ drinking water MCL could be used as the remediation goal for arsenic-polluted groundwaters, this goal is inappropriate, since it is not based on a risk-based approach, but considers economic and political factors. A risk-based groundwater cleanup objective should be adopted for those situations where either mine- or mine tailings-derived arsenic is the source of the arsenic that is polluting the groundwater above background.

The US EPA has presented some potential remediation approaches which will likely involve capping of some of the contaminated areas with a RCRA cap to reduce moisture entering into the area and to immobilize the tailings. There are important issues that must be addressed regarding the monitoring and maintenance of the cap to ensure that its integrity in preventing moisture from entering the tailings is maintained for as long as the capped tailings represent a threat. For many of the contaminated areas, it will likely be necessary to excavate with disposal in a local new landfill or with trucking to an offsite landfill. The preliminary estimated cost for excavation and onsite landfilling is on the order of \$34 million, with offsite disposal costing on the order of $\$ 100$ million. These costs do not include the true long-term costs associated with $a d$ infinitum monitoring and maintenance of the landfill.

There are concerns about the adequacy of minimum RCRA landfills to be able to prevent further environmental pollution by the landfilled tailings and soils due to arsenic-containing leachate that will be generated within the landfill that will ultimately pass through the landfill liner system into the underlying groundwater system. Provisions should be made in remediation of the Lava Cap Mine site to ensure that the remediation approach adopted provides for a high degree of protection of public health and the environment for as long as the waste tailings represent a threat. 


\section{REFERENCES}

ATSDR. 2001. Public Health Assessment for Lava Cap Mine, Nevada City, Nevada County, California, EPA Facility ID: CAD983618893. Agency for Toxic Substances and Disease Registry, US Department of Health and Human Services, Athens, GA.

CH2M Hill. 2001a. Draft Human Health Risk Assessment Report for the Lava Cap Mine Superfund Site, Nevada County, California. Report to the US Environmental Protection Agency, CH2M Hill, Inc., Sacramento, CA, April.

CH2M Hill. 2001b. Final Draft Ecological Risk Assessment for Lava Cap Mine Superfund Site, Nevada City, Nevada County, California. Report to the US Environmental Protection Agency, CH2M Hill, Inc., Sacramento, CA, July.

CH2M Hill. 2001c. Public Release Draft Remedial Investigation Report; Lava Cap Mine Superfund Site, Nevada County, California. Report to the US Environmental Protection Agency, CH2M Hill, Inc., Sacramento, CA, November.

CH2M Hill. 2002. Preliminary Draft Feasibility Study for the Lava Cap Mine Superfund Site, Nevada County, California (not including alternative evaluation). Report to the US Environmental Protection Agency, CH2M Hill, Inc., Sacramento, CA, January.

Davis, A.; Sherwin, D.; Ditmars, R.; Hoenke, K. A. 2001. An Analysis of Soil Arsenic Records of Decision. Environ. Sci. Technol., 35,4396.

Focazio, M. J.; Welch, A. H.; Watkins, S. A.; Helsel, D. R.; and Horn, M. A. 1999. A Retrospective Analysis on the Occurrence of Arsenic in Ground-Water Resources of the United States and Limitations in Drinking-Water-Supply Characterizations. US Geological Survey Water-Resources Investigations Report 99-4279. http://co.water.usgs.gov/trace/pubs/wrir-99-4279/

Frost, F. J.; Tollestrup, K.; Craun, G. F.; Raucher, R.; Stomp, J; and Chwirka, J. 2002. Evaluation of Costs and Benefits of a Lower Arsenic MCL. Journ. AWWA, 94(3),71-80, March.

Lee, G. F. and Jones-Lee, A. 1998a. Assessing the Potential of Minimum Subtitle D Lined Landfills to Pollute: Alternative Landfilling Approaches. Proc. of Air and Waste Management Association $91^{\text {st }}$ Annual Meeting, San Diego, CA, available on CD ROM as paper 98-WA71.04(A46), 40pp, June.

Also available at http://www.gfredlee.com.

Lee, G. F. and Jones-Lee, A. 1998b. Deficiencies in Subtitle D Landfill Liner Failure and Groundwater Pollution Monitoring. Presented at the NWQMC National Conference Monitoring: Critical Foundations to Protect Our Waters. US Environmental Protection Agency, Washington, D.C., July.

NRC. 2001. Arsenic in Drinking Water: 2001 Update. National Research Council, National Academy Press, Washington, D.C. http://www.nap.edu

Salocks, C. B. 1997. Screening Level Evaluation of Potential Health Risks at Lava Cap Mine, Nevada City, California. California Department of Fish and Game Memorandum to Dan Ziarkowski, August 25.

US EPA. 1989. Risk Assessment Guidance for Superfund, Volume I: Human Health Evaluation Manual, Part A. EPA/540/1-89/002. US Environmental Protection Agency, December.

US EPA. 2000. Studies Indicate Arsenic is Primary Concern at Lava Cap Mine Superfund Site. US Environmental Protection Agency, Region IX, San Francisco, CA, September. 
US EPA. 2001a. Lava Cap Mine Superfund Site: Arsenic Poses Unacceptable Risk to Human Health; Arsenic and Metals Pose Potential Risks to the Environment. US Environmental Protection Age ncy, Region IX, San Francisco, CA, November.

US EPA. 2001b. Lava Cap Mine Superfund Site: EPA Studies Cleanup Options, Seeks Public Input. US Environmental Protection Agency, Region IX, San Francisco, CA, November.

US EPA. 2002. Lava Cap Mine California. US Environmental Protection Agency website, June 11.

http://yosemite.epa.gov/r9/sfund/overview.nsf/507c94f730e0ebf488256958005cda5f/091 0a5ef115843c988256802007f6955?OpenDocument

USGS. 2002. Arsenic in ground water of the United States. US Geological Survey website, May 20. http://co.water.usgs.gov/trace/arsenic/ 